\title{
Ipteks Pembukuan Dan Pelaporan Keuangan Bagi UMKM Binaan BMT Mitra Arta Pekanbaru
}

\author{
NENENG SALMIAH $^{1}$; SATRIA TRI NANDA ${ }^{2}$; INTAN ADINO ${ }^{3}$ \\ Universitas Lancang Kuning \\ Jln. Yos Sudarso KM 08 Rumbai Telp. (0761) 52581 \\ E-mail : nenengsalmiah@unilak.ac.id
}

\begin{abstract}
The community service program aims to improve the knowledge of MSME players guided by BMT Mitra Arta in making financial accounting and reporting so that it can be used to assess business performance and increase access to funding, especially financing from BMT Mitra Arta Pekanbaru. The method used in this activity is the method of counseling and training by providing knowledge about financial accounting and reporting of MSMEs in accordance with the SAK EMKM. The activity was continued by providing simulations to make bookkeeping and preparation of financial reports in accordance with the transactions and business types of these MSMEs. In this training activity, MSME players who are guided by the Arta Pekanbaru Partners BMT will be involved collaboratively from the beginning to the end of the activity. Activities include counseling and training with lecture, simulation and question and answer methods. The activity was continued by giving a post test to see the level of success of the activities carried out. The results of the community service activities were as expected, namely an increase in financial accounting and reporting to MSMEs guided by Pekanbaru Arta BMT Mitra and scientific articles to be published at the national level.
\end{abstract}

Keywords: MSMEs, BMT Mitra Arta, Bookkeeping and Financial Reporting

Usaha Mikro, Kecil, dan Menengah (UMKM) merupakan kelompok pelaku ekonomi terbesar dalam perekonomian Indonesia dan salah satu pendorong terdepan dalam pembangunan ekonomi. Sebagai poros kebangkitan perekonomian nasional, UMKM bukan sektor yang tanpa masalah. Kesulitan dalam mengukur kinerja merupakan salah satu kendala UMKM dalam mengevaluasi kinerjanya. Hal ini disebabkan, banyak UMKM lebih berfokus pada kegiatan operasional sehingga pembukuan dan pelaporan keuangan sering terabaikan. Tanpa pembukuan dan pelaporan keuangan yang sesuai dengan SAK EMKM, evaluasi terhadap kinerja UMKM tidak mudah untuk dilakukan serta UMKM sulit untuk memperoleh akses pendanaan dari lembaga keuangan.

Praktek akuntansi keuangan pada UMKM masih rendah dan masih banyak kelemahan, salah satunya disebabkan kurangnya pemahaman Pelaku UMKM terhadap Standar Akuntansi Keuangan
Entitas Mikro Kecil Menengah (SAK EMKM) yang menjadi standar bagi UMKM dalam menyusun laporan keuangan. Hal ini sesuai dengan penelitian Salmiah, dkk (2018) dengan Judul Pemahaman Pelaku UMKM terhadap SAK EMKM : Survey pada UMKM di Pekanbaru dimana hasil penelitian menemukan bahwa tingkat pemahaman Pelaku UMKM terhadap SAK EMKM masih pada tingkat cukup. Tingkat cukup ini dikarenakan sebagian besar UMKM menjawab kuesioner dengan jawaban tidak tahu.

Masih banyak UMKM yang belum memahami asumsi dasar SAK EMKM yaitu konsep entitas bisnis dalam membuat pembukuan dan pelaporan keuangan, yaitu Pelaku UMKM masih belum memisahkan antara asset dan kewajiban entitas bisnis dengan asset dan kewajiban pribadi Pelaku UMKM tersebut. Hal ini tentu saja mengakibatkan Pelaku UMKM tidak mengetahui berapa keuntungan atau kerugian dari usaha yang 
mereka jalankan. Oleh karena itu sekecil apapun usaha yang kita jalankan, pembukuan harus tetap ada.

Menurut Undang-Undang Nomor 28

Tahun 2007, "pembukuan didefinisikan sebagai suatu proses pencatatan yang dilakukan secara teratur untuk mengumpulkan data dan informasi keuangan meliputi harta, kewajiban, modal, penghasilan, dan biaya, serta jumlah harga perolehan dan penyerahan barang atau jasa yang ditutup dengan menyusun laporan keuangan berupa neraca dan laporan laba rugi pada periode tersebut". Dengan kata lain, pembukuan adalah suatu proses pengumpulan data transaksi keuangan suatu usaha yang diakhiri dengan membuat laporan keuangan. Pencatatan transaksi usaha dapat dilakukan dengan menggunakan jurnal umum atau jurnal khusus. Jurnal khusus meliputi jurnal pendapatan/penjualan, jurnal pembelian, jurnal penerimaan kas, jurnal pengeluaran kas, dan jurnal umum.

Untuk menyusun laporan keuangan adalah melalui proses yang sistematis atau dikenal dengan siklus akuntansi, dimulai dari jurnal umum/jurnal khusus, posting ke buku besar, menyusun necara saldo, membuat ayat jurnal penyesuaian, menyusun laporan keuangan, membuat jurnal penutup dan jurnal pembalik. Pelaporan keuangan haruslah disusun sesuai prinsip akuntansi yang berlaku umum yaitu SAK EMKM dimana "laporan keuangan UMKM minimal terdiri dari Laporan Laba/Rugi, Laporan Posisi Keuangan, dan Catatan Atas Laporan Keuangan (CALK)" (DSAK : 2016 : 3 : Par 3.9). Jika laporan keuangan disusun sesuai SAK EMKM maka informasi yang dihasilkan adalah wajar. Dalam menyusun laporan keuangan UMKM, selain harus sesuai SAK EMKM juga harus sesuai dengan jenis usaha yang dijalankan UMKM tersebut, seperti usaha jasa, dagang atau industri.

Dengan membuat pembukuan maka Pelaku UMKM akan dapat mengetahui perkembangan usaha yang dijalankannya, apakah memperoleh laba atau rugi, dapat mengontrol biaya yang dikeluarkan dalam operasional usahanya, dapat mengetahui dengan pasti jumlah hutang dan piutang, dan meminimalkan risiko kehilangan asset, barang atau uang. Dengan kata lain, laporan keuangan yang dihasilkan bertujuan untuk "menyediakan informasi keuangan dan kinerja suatu entitas yang bermanfaat bagi sebagian besar pengguna dalam pengambilan keputusan ekonomik oleh siapapun yang tidak dalam posisi dapat meminta laporan keuangan khusus untuk memenuhi kebutuhan informasi tersebut" (DSAK : 2016 : 2 : Par 2.1). Disamping itu dengan membuat pembukuan dan pelaporan keuangan tentunya UMKM akan mendapat akses pendanaan yang luas baik dari lembaga keuangan bank maupun non bank.

Dengan membuat pembukuan
maka Pelaku UMKM akan dapat mengetahui perkembangan usaha yang dijalankannya, apakah memperoleh laba atau rugi, dapat mengontrol biaya yang dikeluarkan dalam operasional usahanya, dapat mengetahui dengan pasti jumlah hutang dan piutang, dan meminimalkan risiko kehilangan asset, barang atau uang. Dengan kata lain, laporan keuangan yang dihasilkan bertujuan untuk "menyediakan informasi keuangan dan kinerja suatu entitas yang bermanfaat bagi sebagian besar pengguna dalam pengambilan keputusan ekonomik oleh siapapun yang tidak dalam posisi dapat meminta laporan keuangan khusus untuk memenuhi kebutuhan informasi tersebut" (DSAK : 2016 : 2 : Par 2.1). Disamping itu dengan membuat pembukuan dan pelaporan keuangan tentunya UMKM akan mendapat akses pendanaan yang luas baik dari lembaga keuangan bank maupun non bank.

Baitu Maal wa Tamwil (BMT) atau dalam Bahasa Indonesia dikenal sebagai Balai Usaha Mandiri Terpadu adalah "suatu lembaga yang terdiri dari dua istilah, yaitu Baitul Maal dan Baitul Tamwil. Baitul Maal lebih mengarah pada 
usaha-usaha pengumpulan dana dan penyaluran dana yang nonprofit, seperti : zakat, infaq, dan sedekah. Adapun Baitul Tamwil sebagai usaha pengumpulan dan penyaluran dana komersial" (Huda dan Heykal : 2010 : 363). Beberapa pakar lain menyebutkan, BMT adalah "lembaga keuangan mikro (LKM) yang beroperasi berdasarkan prinsip-prinsip Syariah. BMT adalah kelompok swadaya masyarakat sebagai lembaga ekonomi rakyat yang berupaya mengembangkan usaha-usaha produktif dan investasi dengan sistem bagi hasil (profit sharing) untuk meningkatkan kualitas ekonomi pengusaha kecil dalam upaya pengentasan kemiskinan" (Yuningrum : 2012 : 25-26). Kegiatan mengembangkan usaha-usaha produktif dan investasi dalam meningkatkan kualitas kegiatan ekonomi UMKM dengan cara, antara lain mendorong kegiatan menabung dan menunjang pembiayaan kegiatan ekonomi UMKM. Selain itu, BMT juga menerima titipan zakat, infak, sedekah, hibah, dan wakaf serta menyalurkannya sesuai dengan peraturan dan amanahnya. Dengan kata lain, secara konsep, BMT memiliki dua kegiatan sekaligus yaitu kegiatan yang bertujuan social oriented dan profit oriented.

\section{Diperlukan}

profesionalisme pengelola BMT yang memahami benar ilmu dan pengalaman antara lain tentang perilaku nasabah, manajemen kas, manajemen kredit, dan manajemen risiko, sehingga setiap peluang yang ada dapat diambil untuk meningkatkan kinerja BMT. Dengan demikian BMT sebagai salah satu lembaga keuangan syariah mempunyai peran penting dalam memberdayakan ekonomi umat, khususnya bagi kalangan UMKM serta harus mengikuti dan melaksanakan ketentuan regulasi yang dikeluarkan oleh pemerintah yang mengatur kegiatan usaha yang berbasis syariah dalam operasionalnya.

Pesatnya aktivias ekonomi masyarakat berbasis syariah membuat kehadiran regulasi yang mandiri menjadi sebuah keniscayaan. Bank-bank Syariah dan BPRS tunduk pada peraturan Bank Indonesia. Sedangkan Lembaga Keuangan Mikro (LKM) dalam bentuk BMT hingga saat ini belum ada regulasi yang mandiri dan realitanya berbadan hukum koperasi sehingga tunduk terhadap peraturan perkoperasian. Sedangkan ditinjau dari segmen usahanya BMT juga termasuk UKM karenanya juga mengikuti peraturan-peraturan terkait pembinaan dan pengembangan UMKM.

Kriteria UMKM sesuai rentang kuantitatif sebagaimana dijelaskan dalam Pasal 6 dalam UU No 20 Tahun 2008 yaitu Usaha Mikro memiliki kekayaan bersih paling banyak Rp50.000.000, tidak termasuk tanah dan bangunan tempat usaha atau memiliki hasil penjualan tahunan paling banyak Rp300.000.000; Usaha Kecil memiliki kekayaan bersih lebih dari Rp50.000.000 sampai dengan paling banyak Rp500.000.000, tidak termasuk tanah dan bangunan tempat usaha atau memiliki hasil penjualan tahunan lebih dari Rp300.000.000 sampai dengan paling banyak Rp2.500.000.000; Usaha Menengah memiliki kekayaan bersih lebih dari Rp500.000.000 sampai dengan paling banyak Rp10.000.000.000, tidak termasuk tanah dan bangunan tempat usaha atau memiliki hasil penjualan tahunan lebih dari Rp2.500.000.000 sampai dengan paling banyak Rp50.000.000.000.

BMT Mitra Arta yang beralamat di Jalan Khayangan/Sekolah No.80 E Rumbai Pesisir Pekanbaru adalah lembaga ekonomi rakyat yang menjalankan usaha memenuhi konsep social oriented (Baitul Maal) dan profit oriented (Tamwil). Dalam menjalankan fungsi sosial, BMT Mitra Arta menjalankan Program Pusako yaitu paket sedekah sembako yang diberikan kepada fakir miskin / dhuafa menjelang Hari Raya Idul Fitri. Paket ini berbentuk sedekah dengan nilai $\mathrm{Rp}$ 85.000/paket dari para donator untuk dibelikan ke paket sembako yang nantinya diserahkan kepada fakir miskin/dhuafa. Sedangkan dalam menjalankan fungsinya 
sebagai lembaga yang bertujuan profit oriented, BMT Mitra Arta menjalankan kegiatan ekonomi dengan menghimpun dan menyalurkan dana kepada anggota dan masyarakat lainnya, yang dalam hal ini adalah UMKM. Pada tahap awal pembuatan proposal PKM, Tim Pelaksana PKM melakukan wawancara dengan Manajemen BMT Mitra Arta sebagai Calon mitra PKM.

Berdasarkan hasil wawancara Tim Pelaksana PKM dengan Manajemen BMT Mitra Arta, diperoleh informasi bahwa hingga akhir tahun 2018, jumlah anggota dan masyarakat lainnya yang memperoleh pembiayaan dari BMT Mitra Arta adalah sebanyak 79 UMKM dengan jenis usaha yang berbeda-beda.

Dalam menjalankan kegiatan penyaluran dana, BMT menerapkan sesuai syariah yaitu dengan bagi hasil. Oleh karena itu, setelah BMT Mitra Arta menyalurkan dana kepada anggota dan masyarakat lainnya yang dalam hal ini adalah UMKM maka BMT Mitra Arta perlu melakukan pembinaaan dan pengawasan terhadap usaha yang dijalankan UMKM tersebut baik pembinaan mengenai produksi, pemasaran dan pembukuan bagi UMKM. Kegiatan pembinaan dan pengawasan ini diharapkan berdampak pada pengembangan usaha Pelaku UMKM itu sendiri yang pada akhirnya akan berdampak pada kelancaran pengembalian dana yang telah disalurkan, begitu juga dengan bagi hasil sebagai pendapatan yang akan diterima BMT. Dengan demikian 79 UMKM tersebut sekaligus menjadi UMKM binaan BMT Mitra Arta.

Langkah awal BMT Mitra Arta dalam melakukan pembinaan dan pengawasan kepada UMKM, adalah dengan melakukan survey. Salah satu surveinya adalah survey tentang penggunaan pembukuan bagi UMKM. Hasil survey menunjukkan, dari 79 UMKM binaan BMT Mitra Arta tersebut hanya 25\% yang membuat pembukuan. Dengan kata lainnya, ada 75\% UMKM Binaan BMT Mitra Arta yang belum membuat pembukuan. Salah satu faktornya adalah masalah kompetensi Sumber Daya Manusia (SDM) yang masih rendah yaitu Pelaku UMKM tersebut belum memiliki pengetahuan dan kemampuan untuk membuat pembukuan dan pelaporan keuangan. Oleh karena itu, Manajemen BMT Mitra Arta berkesimpulan perlu diadakannya pelatihan pembukuan guna meningkatkan pengetahuan dan kemampuan SDM.

Dari hasil survey Manajemen BMT Mitra Arta menemukan ada tujuh puluh lima persen $(75 \%)$ dari 79 UMKM Binaan BMT Mitra Arta tersebut yang belum membuat pembukuan dan pelaporan keuangan. Hal ini, salah satunya disebabkan rendahnya kompetensi SDM yaitu Pelaku UMKM tersebut belum memiliki pengetahuan dan kemampuan.

Dari analisis situasi yang penulis uraikan di atas maka penulis menemukan permasalahan mitra, yaitu sebagian besar UMKM Binaan BMT Mitra Arta belum membuat pembukuan dan pelaporan keuangan karena belum pernah mendapatkan penyuluhan pengetahuan tentang pembukuan dan pelaporan keuangan.

Target dari pelaksanaan kegiatan pengabdian kepada masyarakat ini adalah pemberian pengetahuan dalam bentuk penyuluhan dan simulasi tentang pembukuan dan pelaporan keuangan kepada UMKM Binaan BMT Mitra Arta Pekanbaru sehingga UMKM Binaan Mitra Arta memiliki pengetahuan tentang pembukuan dan pelaporan keuangan,

Luaran pada pengabdian ini adalah peningkatan pengetahuan tentang pembukuan dan pelaporan keuangan, artikel ilmiah yang dipublikasikan minimal pada prosiding yang ber-ISSN, dan pengayaan bahan ajar terutama untuk Matakuliah Pengantar Akuntansi I. 


\section{METODE}

Dalam rangka mencapai target yang telah diuraikan di atas, maka pelaksanaan kegiatan pengabdian kepada masyarakat ini dilaksanakan dengan melakukan beberapa metode yaitu dengan melaksanakan pre test dan post test, ceramah dan penyuluhan, simulasi, diskusi serta indikator untuk mengukur keberhasilan pelaksanaan kegiatan.

\section{HASIL}

Kegiatan pengabdian kepada masyarakat ini bertujuan untuk memberikan pengetahuan tentang pembukuan dan pelaporan keuangan. Peserta yang ikut dalam kegiatan pengabdian kepada masyarakat ini sebanyak 25 orang terdiri dari Ketua pengurus BMT Mitra Arta dan staf serta pelaku UMKM Binaan BMT Mitra Arta .

Metode pelaksanaan kegiatan terdiri dari melakukan pre test, penyampaian Materi yang berkaitan dengan pembukuan dan pelaporan keuangan bagi UMKM serta pelatihan dan simulasi menyelesaikan satu kasus transaksi pada salah satu UMKM bidang jasa mulai dari mencatat transaksi menggunakan jurnal khusus yang terdiri dari jurnal pendapatan, jurnal pembelian, jurnal penerimaan kas, jurnal pengeluaran kas, dan jurnal umum, memposting ke buku besar, menyusun neraca saldo sampai menyusun laporan keuangan. Kegiatan dilanjutkan dengan diskusi melalui tanya jawab antara mitra dan tim pengabdian, serta melakukan post test untuk mengevaluasi hasil dari kegiatan pengabdian yang telah dilaksanakan. Indikator keberhasilan pelaksanaan kegiatan pengabdian kepada masyarakat ini, dapat dilihat dari kehadiran peserta sesuai yang direncanakan serta adanya peningkatan hasil post-test.

Diawal penyampaian materi diperoleh informasi bahwa sebagian besar peserta belum memiliki pengetahuan tentang pembukuan dan pelaporan keuangan. Melalui kegiatan pengabdian kepada masyarakat ini, kami dari tim dosen Fakultas Ekonomi Universitas Lancang Kuning yang memiliki kompetensi di bidang akuntansi, memberikan pemahaman tentang pentingnya pembukuan dan menyusun laporan keuangan agar Pelaku UMKM binaan BMT Mitra Arta dapat mengetahui perkembangan usaha yang dijalankannya serta mengambil keputusan yang tepat. Kemudian tim pelaksana memberikan pengetahuan tentang pembukuan dan penyusunan laporan keuangan bagi UMKM. Penyusunan laporan keuangan bagi UMKM tentunya harus sesuai dengan SAK EMKM.

Menurut Undang-Undang Nomor 28 Tahun 2007, pembukuan didefinisikan sebagai suatu proses pencatatan yang dilakukan secara teratur untuk mengumpulkan data dan informasi keuangan meliputi harta, kewajiban, modal, penghasilan, dan biaya, serta jumlah harga perolehan dan penyerahan barang atau jasa yang ditutup dengan menyusun laporan keuangan berupa neraca dan laporan laba rugi pada periode tersebut. Proses yang sistematis dimulai dari pencatatan. Pencatatan yang sederhana adalah menggunakan jurnal khusus, terdiri dari jurnal pendapatan/penjualan, jurnal pembelian, jurnal penerimaan kas, jurnal pengeluaran kas, dan jurnal umum. Kemudian dilanjutkan dengan memposting ke buku besar dan menyusun neraca saldo. Dan diakhiri dengan menyusun laporan keuangan yang sesuai dengan SAK yaitu SAK EMKM. Laporan keuangan yang sesuai dengan SAK EMKM terdiri dari Laporan Laba/Rugi, Laporan Posisi Keuangan, dan Catatan atas Laporan Keuangan (CALK).

Pada saat penyampaian materi dalam bentuk penyuluhan, terlihat antusiasme peserta untuk dapat memiliki pengetahuan tentang pembukuan dan penyusunan laporan keuangan karena peserta menyadari bahwa selama ini tidak dapat mengetahui kinerja usahanya dan terkendala dalam mengembangkan usaha karena sulitnya mendapatkan tambahan pinjaman atau pembiayaan baik dari bank konvensional maupun dari BMT Mitra Arta itu sendiri. Adapun suasana pada saat pelaksanaan pengabdian kepada masyarakat 
dapat kita lihat pada gambar 1 ,

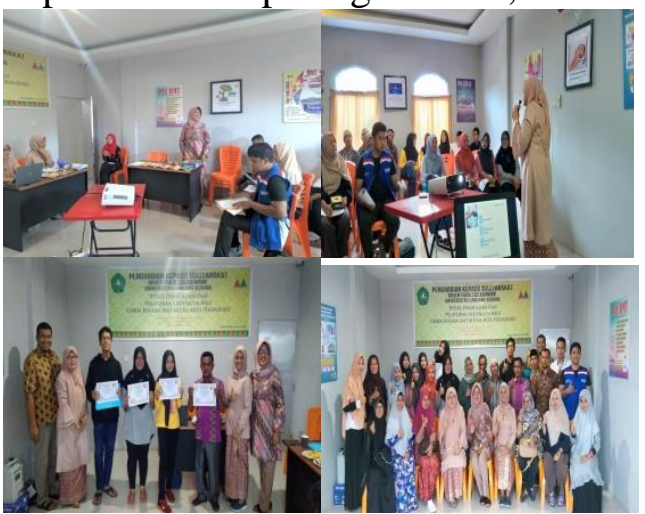

Gambar 1. Suasana pelaksanaan PKM

Setelah memberikan penyuluhan tentang pengetahuan pembukuan dan pelaporan keuangan, kegiatan pengabdian kepada masyarakat dilanjutkan dengan pelatihan dan simulasi yaitu mulai dari mencatat transaksi usaha di bidang jasa salah satu peserta menggunakan jurnal khusus, memposting ke buku besar, menyusun neraca saldo, sampai menyusun laporan keuangan. Pada kegiatan simulasi, sebagian besar peserta dapat mengikutinya dengan baik dan ada sebagian peserta yang langsung mencoba mencatat transaksi usahanya, tentunya dengan mendapat pendampingan dari tim pelaksana.

Hasil yang dicapai dari kegiatan pengabdian kepada masyarakat bagi UMKM binaan BMT Mitra Arta ini kami peroleh dengan membandingkan persentase jawaban kuesioner setelah penyampaian materi (post test) tentang pembukuan dan pelaporan keuangan dengan persentase jawaban kuesioner sebelum penyampaian materi (pre test) tentang hal yang sama. Persentase jawaban dari post test dan pre test tersebut dapat kita lihat pada tabel 1 .

Berdasarkan tabel 1 jawaban pre-test pernyataan No.1 : "Saya mencatat transaksi pendapatan kredit ke dalam jurnal pendapatan/penjualan", dapat kita lihat bahwa pelaku UMKM binaan BMT Mitra Arta Pekanbaru, menjawab dengan sangat setuju sebesar $8,0 \%$, setuju sebesar $12,0 \%$, dan tidak tahu sebesar 80,0\%. Ini menunjukkan, sebelum dilakukan kegiatan pengabdian kepada masyarakat, sebagian besar pelaku UMKM belum memiliki pengetahuan tentang pembukuan khususnya pencatatan transaksi pendapatan kredit ke dalam jurnal pendapatan/penjualan. Dan setelah diberikan penyuluhan pengetahuan tentangnya pembukuan dan pelaporan keuangan, jawaban post-test yaitu sangat setuju meningkat sebesar $32,0 \%$ atau menjadi sebesar 40,0\%, jawaban setuju meningkat sebesar $40,0 \%$ atau menjadi sebesar 52\% sedangkan jawaban tidak tahu turun drastis sebesar $72,0 \%$ atau menjadi sebesar $8,0 \%$. Hal ini menunjukkan, setelah dilakukan kegiatan pengabdian kepada masyarakat, sebagian besar pelaku UMKM binaan BMT Mitra Arta Pekanbaru sudah memiliki pengetahuan tentang pembukuan atau ada peningkatan yang cukup besar dalam hal jurnal pendapatan/penjualan.

Jawaban pre-test pernyataan No.2 : "Saya mencatat transaksi pendapatan tunai ke dalam jurnal penerimaan kas", dapat kita lihat bahwa pelaku UMKM binaan BMT Mitra Arta Pekanbaru, menjawab dengan sangat setuju sebesar $4,0 \%$, setuju sebesar $32,0 \%$, tidak tahu sebesar $60,0 \%$ dan sangat tidak setuju $4,0 \%$. Ini menunjukkan, sebelum dilakukan kegiatan pengabdian kepada masyarakat, sebagian besar pelaku UMKM belum memiliki pengetahuan tentang pembukuan khususnya pencatatan transaksi pendapatan tunai ke dalam jurnal penerimaan kas. Dan setelah diberikan penyuluhan pengetahuan tentangnya pembukuan dan pelaporan keuangan, jawaban post-test yaitu sangat setuju meningkat sebesar $28,0 \%$ atau menjadi sebesar $32,0 \%$, setuju meningkat sebesar $24,0 \%$ atau menjadi sebesar 56,0, sedangkan jawaban tidak tahu turun drastis sebesar $48,0 \%$ atau menjadi $12,0 \%$. Begitu juga dengan jawaban sangat tidak setuju turun dari $4,0 \%$ menjadi $0,0 \%$. Hal ini menunjukkan, setelah dilakukan kegiatan pengabdian kepada masyarakat, sebagian besar Pelaku UMKM binaan BMT Mitra Arta Pekanbaru sudah memiliki pengetahuan tentang pembukuan atau ada peningkatan yang cukup besar dalam hal jurnal penerimaan kas. 
Jawaban pre-test No.3 : "Saya mencatat transaksi pembelian kredit ke dalam jurnal pembelian", dapat kita lihat bahwa pelaku UMKM binaan BMT Mitra Arta Pekanbaru, menjawab dengan sangat setuju sebesar $0,0 \%$, setuju sebesar $20,0 \%$, dan tidak tahu sebesar $80,0 \%$. Ini menunjukkan, sebelum dilakukan kegiatan pengabdian kepada masyarakat, sebagian besar pelaku UMKM belum memiliki pengetahuan tentang pembukuan khususnya pencatatan transaksi pembelian kredit ke dalam jurnal pembelian. Dan setelah diberikan penyuluhan pengetahuan tentangnya pembukuan dan pelaporan keuangan, jawaban post-test yaitu sangat setuju meningkat sebesar $44,0 \%$ atau menjadi sebesar $44,0 \%$, setuju meningkat sebesar $28,0 \%$ atau menjadi sebesar $48 \%$, sedangkan jawaban tidak tahu turun drastis sebesar $72,0 \%$ atau menjadi sebesar $8,0 \%$. Hal ini menunjukkan, setelah dilakukan kegiatan pengabdian kepada masyarakat, sebagian besar Pelaku UMKM binaan BMT Mitra Arta Pekanbaru sudah memiliki pengetahuan tentang pembukuan atau ada peningkatan yang cukup besar dalam hal jurnal pembelian.

Pernyataan No.4 : "Saya mencatat pembelian tunai ke dalam jurnal pengeluaran kas", dapat kita lihat bahwa pelaku UMKM binaan BMT Mitra Arta Pekanbaru, menjawab dengan sangat setuju sebesar $16,0 \%$, setuju sebesar $20,0 \%$, dan menjawab tidak tahu sebesar $64,0 \%$. Ini menunjukkan, sebelum dilakukan kegiatan pengabdian kepada masyarakat, sebagian besar pelaku UMKM belum memiliki pengetahuan tentang pembukuan khususnya pencatatan transaksi pembelian tunai ke dalam jurnal pengeluaran kas. Dan setelah diberikan penyuluhan pengetahuan tentangnya pembukuan dan pelaporan keuangan, jawaban post-test yaitu sangat setuju meningkat sebesar $20,0 \%$ atau menjadi sebesar 36,0\%, setuju meningkat sebesar $40,0 \%$ atau menjadi $60,0 \%$, sedangkan jawab tidak tahu turun drastis sebesar $60,0 \%$ atau menjadi $4,0 \%$. Hal ini menunjukkan, setelah dilakukan kegiatan pengabdian kepada masyarakat, sebagian besar Pelaku UMKM binaan BMT Mitra Arta Pekanbaru sudah memiliki pengetahuan tentang pembukuan atau ada peningkatan yang cukup besar dalam hal jurnal pengeluaran kas.

Jawaban pre-test No.5 : "Saya mencatat transaksi yang tidak bisa dicatat ke dalam 4 jurnal di atas ke jurnal umum”, dapat kita lihat bahwa pelaku UMKM binaan BMT Mitra Arta Pekanbaru, menjawab dengan sangat setuju sebesar $0 \%$, setuju sebesar $20,0 \%$, dan menjawab tidak tahu sebesar $80,0 \%$. Ini menunjukkan, sebelum dilakukan kegiatan pengabdian kepada masyarakat, sebagian besar pelaku UMKM belum memiliki pengetahuan tentang pembukuan khususnya pencatatan transaksi ke dalam jurnal umum. Dan setelah diberikan penyuluhan pengetahuan tentangnya pembukuan dan pelaporan keuangan, jawaban post-test yaitu sangat setuju meningkat sebesar $24,0 \%$ atau menjadi sebesar $24,0 \%$, setuju meningkat sebesar $48,0 \%$ atau menjadi sebesar $68,0 \%$ sedangkan jawaban tidak tahu turun drastis sebesar $72,0 \%$ atau menjadi $8,0 \%$. Hal ini menunjukkan, setelah dilakukan kegiatan pengabdian kepada masyarakat, sebagian besar Pelaku UMKM binaan BMT Mitra Arta Pekanbaru sudah memiliki pengetahuan tentang pembukuan atau ada peningkatan yang cukup besar dalam hal jurnal umum.

Jawaban pre-test No.6 : "Setelah mencatat transaksi kemudian memposting ke buku besar lalu menyusun neraca saldo", dapat kita lihat bahwa pelaku UMKM binaan BMT Mitra Arta Pekanbaru, menjawab dengan sangat setuju sebesar $4,0 \%$. setuju sebesar $20,0 \%$, tidak tahu sebesar $72,0 \%$ dan tidak setuju sebesar 4,0\%. Ini menunjukkan, sebelum dilakukan kegiatan pengabdian kepada masyarakat, sebagian besar pelaku UMKM belum memiliki pengetahuan tentang pembukuan khususnya siklus akuntansi yaitu setelah mencatat transaksi ke dalam jurnal khusus/jurnal umum maka dilanjutkan dengan memposting ke buku besar dan menyusun neraca saldo. Dan setelah diberikan penyuluhan pengetahuan 
tentangnya pembukuan dan pelaporan keuangan, jawaban post-test yaitu sangat setuju meningkat sebesar $24,0 \%$ atau menjadi sebesar $28,0 \%$, setuju meningkat sebesar $48,0 \%$ atau menjadi sebesar $68 \%$, sedangkan jawaban tidak tahu turun drastis sebesar $68,0 \%$ atau menjadi sebesar $4,0 \%$. Hal ini menunjukkan, setelah dilakukan kegiatan pengabdian kepada masyarakat, sebagian besar Pelaku UMKM binaan BMT Mitra Arta Pekanbaru sudah memiliki pengetahuan tentang pembukuan atau ada peningkatan yang cukup besar dalam hal siklus akuntansi yaitu dari jurnal khusus/jurnal umum dilanjutkan memposting ke buku besar dan menyusun neraca saldo.

Jawaban pre-test No.7 : "Setelah neraca saldo maka disusun laporan keuangan terdiri dari Laporan L/R, Laporan posisi keuangan, dan catatan atas laporan keuangan", dapat kita lihat bahwa pelaku UMKM binaan BMT Mitra Arta Pekanbaru, menjawab dengan sangat setuju sebesar $4,0 \%$, setuju sebesar $12,0 \%$ dan jawaban tidak tahu sebesar $84,0 \%$. Ini menunjukkan, sebelum dilakukan kegiatan pengabdian kepada masyarakat, sebagian besar pelaku UMKM belum memiliki pengetahuan tentang pembukuan khususnya siklus akuntansi yaitu setelah menyusun neraca saldo maka disusun laporan keuangan yang terdiri dari Laporan L/R, Laporan posisi keuangan, dan catatan atas laporan keuangan (CALK). Dan setelah diberikan penyuluhan pengetahuan tentangnya pembukuan dan pelaporan keuangan, jawaban post-test yaitu sangat setuju meningkat sebesar $36,0 \%$ atau menjadi sebesar $40,0 \%$, setuju meningkat sebesar $44,0 \%$ atau menjadi sebesar 56,0\%, sedangkan jawaban tidak tahu turun drastis sebesar $80,0 \%$ atau menjadi sebesar $4,0 \%$. Hal ini menunjukkan, setelah dilakukan kegiatan pengabdian kepada masyarakat, sebagian besar Pelaku UMKM binaan BMT Mitra Arta Pekanbaru sudah memiliki pengetahuan tentang pembukuan atau ada peningkatan yang cukup besar dalam hal siklus akuntansi yaitu setelah menyusun neraca saldo maka disusun laporan keuangan. Jawaban pre-test No.8 : "Laporan L/R berisi informasi tentang pendapatan dan beban", dapat kita lihat bahwa pelaku UMKM binaan BMT Mitra Arta Pekanbaru, menjawab dengan sangat setuju sebesar $16,0 \%$, setuju sebesar $20,0 \%$, dan jawaban tidak tahu sebesar $64,0 \%$. Ini menunjukkan, sebelum dilakukan kegiatan pengabdian kepada masyarakat, sebagian besar pelaku UMKM belum memiliki pengetahuan tentang pelaporan keuangan khususnya informasi yang terdapat dalam Laporan L/R. Dan setelah diberikan penyuluhan pengetahuan tentangnya pembukuan dan pelaporan keuangan, jawaban post-test yaitu sangat setuju meningkat sebesar $32,0 \%$ atau menjadi sebesar $48,0 \%$, setuju meningkat sebesar $24,0 \%$ atau menjadi sebesar $44,0 \%$ sedangkan jawaban tidak tahu turun drastis menjadi sebesar 56,0\% atau menjadi sebesar $8,0 \%$. Hal ini menunjukkan, setelah dilakukan kegiatan pengabdian kepada masyarakat, sebagian besar Pelaku UMKM binaan BMT Mitra Arta Pekanbaru sudah memiliki pengetahuan tentang pembukuan dan pelaporan keuangan atau ada peningkatan yang cukup besar dalam hal pengetahuan tentang informasi yang terdapat dalam Laporan L/R.

Jawaban pre-test No.9 : "Laporan posisi keuangan berisi informasi tentang asset, kewajiban, dan modal", dapat kita lihat bahwa pelaku UMKM binaan BMT Mitra Arta Pekanbaru, menjawab dengan sangat setuju sebesar $4,0 \%$, setuju sebesar $12,0 \%$, dan jawaban tidak tahu sebesar $84,0 \%$. Ini menunjukkan, sebelum dilakukan kegiatan pengabdian kepada masyarakat, sebagian besar pelaku UMKM belum memiliki pengetahuan tentang pelaporan keuangan khususnya informasi yang terdapat dalam Laporan posisi keuangan. Dan setelah diberikan penyuluhan pengetahuan tentangnya pembukuan dan pelaporan keuangan, jawaban post-test yaitu sangat setuju meningkat sebesar $32,0 \%$ atau menjadi sebesar $36,0 \%$, setuju meningkat sebesar $36,0 \%$ atau menjadi sebesar $48,0 \%$ sedangkan jawaban tidak tahu turun drastic 
sebesar $68,0 \%$ atau menjadi sebesar $16,0 \%$. Hal ini menunjukkan, setelah dilakukan kegiatan pengabdian kepada masyarakat, sebagian besar Pelaku UMKM binaan BMT Mitra Arta Pekanbaru sudah memiliki pengetahuan tentang pembukuan dan pelaporan keuangan atau ada peningkatan yang cukup besar dalam hal pengetahuan tentang informasi yang terdapat dalam Laporan posisi keuangan.

Jawaban pre-test No.10 : "Catatan atas laporan keuangan berisi informasi tentang laporan keuangan telah disusun sesuai SAK EMKM, ikhtisar kebijakan akuntansi, dan informasi tambahan", dapat kita lihat bahwa pelaku UMKM binaan BMT Mitra Arta Pekanbaru, menjawab dengan sangat setuju sebesar $4,0 \%$, setuju sebesar $4,0 \%$, dan jawaban tidak tahu sebesar $92,0 \%$. Ini menunjukkan, sebelum dilakukan kegiatan pengabdian kepada masyarakat, sebagian besar pelaku UMKM belum memiliki pengetahuan tentang pelaporan keuangan khususnya informasi yang terdapat dalam Catatan Atas Laporan Keuangan (CALK). Dan setelah diberikan penyuluhan pengetahuan tentangnya pembukuan dan pelaporan keuangan, jawaban post-test yaitu sangat setuju meningkat sebesar $32,0 \%$ atau menjadi sebesar $36,0 \%$, setuju meningkat sebesar 52,0\% atau menjadi sebesar 56,0\% sedangkan jawaban tidak tahu turun drastic sebesar $84,0 \%$ atau menjadi sebesar $8,0 \%$. Hal ini menunjukkan, setelah dilakukan kegiatan pengabdian kepada masyarakat, sebagian besar Pelaku UMKM binaan BMT Mitra Arta Pekanbaru sudah memiliki pengetahuan tentang pembukuan dan pelaporan keuangan atau ada peningkatan yang cukup besar dalam hal pengetahuan tentang informasi yang terdapat dalam Catatan Atas Laporan Keuangan (CALK).

\section{PEMBAHASAN}

Hasil yang dicapai dari kegiatan pengabdian kepada masyarakat yang telah dilakukan, secara garis besar mencakup beberapa komponen, yaitu keberhasilan target jumlah kehadiran peserta, ketercapaian target materi yang telah direncanakan, ketercapaian tujuan pengabdian kepada masyarakat dan kemampuan peserta dalam penguasaan materi. Ketercapaian target jumlah peserta dapat dilihat dari jumlah peserta yang ditargetkan adalah 25 orang dan realisasi yang hadir juga 25 orang. Dengan kata lain realisasi jumlah kehadiran peserta sebesar $100 \%$. Persentase kehadiran $100 \%$ ini merupakan indikator keberhasilan pencapaian target dari jumlah peserta. Materi yang telah dipersiapkan meliputi materi tentang apa itu pembukuan, pentingnya laporan keuangan dan penyusunan laporan keuangan UMKM sesuai dengan SAK EMKM. Kegiatan dilanjutkan dengan pelatihan dan simulasi pembukuan UMKM bidang jasa mulai dari mencatat transaski menggunakan jurnal khusus yaitu jurnal penjualan/pendapatan, kurnal penerimaan kas, jurnal pembelian, jurnal pengeluaran kas, dan jurnal umum, memposting ke buku besar, menyusun neraca saldo dan laporan keuangan yang terdiri dari Laporan L/R, Laporan posisi keuangan, Catatan Atas Laporan Keuangan (CALK).

Semua materi yang telah dpersiapkan, dapat disampaikan kepada peserta sesuai waktu yang telah ditentukan dan peserta dapat mengikutinya dengan baik. Begitu juga dengan kegiatan pelatihan dan simulasi, sebagian besar peserta antusias mengikutinya. Kemudian tim PKM juga memberikan kesempatan kepada peserta untuk mengajukan pertanyaan terkait materi yang disampaikan. Target penyampaian materi, pelatihan dan simulasi telah tercapai $100 \%$ karena semua materi yang telah dipersiapkan, secara keseluruhan terlaksana dengan baik dan pertanyaan-pertanyaan yang diajukan peserta menunjukkan adanya peningkatan pengetahuan peserta tentang pembukuan dan pelaporan keuangan. Dengan demikian, dapat disimpulkan bahwa tujuan kegiatan Pengabdian kepada Masyarakat telah tercapai sesuai tujuan yang diharapkan.

Berdasarkan jawaban pre dan post test pada tabel 1 pernyataan No. 1 sampai No.5, dapat kita lihat bahwa setelah 
diberikan penyuluhan, sebagian besar pelaku UMKM binaan BMT Mitra Arta Pekanbaru, sudah memiliki pengetahuan tentang pembukuan khususnya pencatatan transaksi menggunakan jurnal khusus yang terdiri dari jurnal penjualan/pendapatan, jurnal penerimaan kas, jurnal pembelian, jurnal pengeluaran kas, dan jurnal umu. Hal ini menunjukkan bahwa semakin banyak Pelaku UMKM binaan BMT Mitra Arta yang sudah memiliki pengetahuan pembukuan dan pelaporan keuangan khususnya pencatatan menggunakan jurnal khusus. Hal ini menunjukkan bahwa target kegiatan pengabdian kepada masyarakat yaitu untuk pemberian pengetahuan pembukuan dan pelaporan keuangan kepada UMKM binaan BMT Mitra Arta, sudah tercapai.

Berdasarkan jawaban pre dan post test pada tabel 1 pernyataan No.6 dan No.7 dapat kita lihat bahwa setelah diberikan penyuluhan, sebagian besar pelaku UMKM binaan BMT Mitra Arta Pekanbaru, sudah memiliki pengetahuan tentang pembukuan khususnya siklus akuntansi setelah pencatatan transaksi menggunakan jurnal khusus/jurnal umum dilanjutkan dengan memposting ke buku besar dan menyusun nerasa saldo. Lalu dari neraca saldo dilanjutkan menyusun laporan keuangan. Hal ini menunjukkan bahwa target kegiatan pengabdian kepada masyarakat yaitu untuk pemberian pengetahuan pembukuan dan pelaporan keuangan kepada UMKM binaan BMT Mitra Arta, sudah tercapai.

Berdasarkan jawaban pre dan post test pada table 1 pernyataan No.8 sampai No.10 dapat kita lihat bahwa setelah diberikan penyuluhan pengetahuan tentang pembukuan dan pelaporan keuangan maka sebagian besar peserta sudah mengetahui informasi yang terdapat dalam masingmasing laporan keuangan, baik Laporan L/R, Laporan posisi keuangan, maupun Cinformasi dalam Catatan Atas Laporan Keuangan (CALK). Hal ini menunjukkan bahwa target kegiatan pengabdian kepada masyarakat yaitu untuk memberikan pengetahuan pembukuan dan pelaporan keuangan kepada UMKM binaan BMT Mitra
Arta, sudah tercapai.

Pengetahuan tentang pembukuan dan pelaporan keuangan yang telah diperoleh dari kegiatan PKM ini hendaknya dapat diterapkan bagi UMKM binaan BMT Mitra Arta Pekanbaru, sehingga UMKM binaan BMT Mitra Arta dapat mengetahui kinerja usahanya, mengetahui posisi keuangan, lebih mudah dalam proses pendanaan yaitu tambahan pembiayaan dari BMT Mitra Arta. Disamping itu, pembukuan dan pelaporan keuangan yang dibuat UMKM binaan BMT Mitra Arta tentunya memudahkan bagi pengurus dan staf BMT Mitra Arta melakukan monitoring terhadap perkembangan usaha yang dijalankan pelaku UMKM tersebut.

\section{SIMPULAN}

Sesuai dengan target kegiatan pengabdian kepada masyarakat yang telah ditetapkan, dapat diambil kesimpulan yaitu pemberian pengetahuan dalam bentuk penyuluhan dan simulasi tentang pembukuan dan pelaporan keuangan kepada UMKM Binaan BMT Mitra Arta Pekanbaru telah terlaksana dengan baik dan hasilnya sebagian Pelaku UMKM yang hadir tersebut sudah memiliki pengetahuan tentang pembukuan dan pelaporan keuangan.

Berdasarkan kesimpulan di atas, maka kami dari Tim Dosen Fakultas Ekonomi Universitas Lancang Kuning dapat memberikan saran sebagai berikut : pertama, perlu adanya kegiatan pemberian pengetahuan pembukuan dan pelaporan keuangan secara berkelanjutan kepada UMKM Binaan BMT Mitra Arta lainnya. Kedua, perlu dilakukan pendampingan bagi UMKM Ninaan BMT Mitra Arta dalam membuat pembukuan dan pelaporan keuangan sesuai SAK EMKM dari pihak yang berkompeten, salah satunya dari pihak akademisi. 


\section{DAFTAR RUJUKAN}

DSAK IAI, 2016. Standar Akuntansi Keuangan Entitas Mikro, Kecil, dan Menengah (SAK EMKM), Ikatan Akuntan Indonesia

Huda Nurul, Heykal Mohamad, 2010, Lembaga Keuangan Islam Tinjauan Teoretis dan Praktis, Kencana, Jakarta

Salmiah et.al, 2018, Pemahaman Pelaku UMKM terhadap SAK EMKM Survey pada UMKM yang terdaftar di Dinas Koperasi dan UKM Kota Pekanbaru, Jurnal Akuntansi Dewantara : Vol.2 No.2 Tahun 2018

Undang-Undang Republik Indonesia No.20 Tahun 2008 tentang Usaha Mikro, Kecil, dan Menengah

Undang-Undang Nomor 28 Tahun 2007 tentang Ketentuan Umum dan Tata Cara Perpajakan

Yuningrum Heny, 2012, Mengukur Kinerja Operasional BMT Pada Tahun 2010 Dari Segi Efisiensi Dengan Data Envelopment Analysis, IAIN Walisongo Semarang 